Article

\title{
Effect of gas diffusion electrode parameters on anion exchange membrane fuel cell performance
}

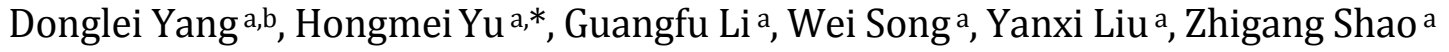 \\ a Dalian National Laboratory for Clean Energy, Dalian Institute of Chemical Physics, Chinese Academy of Science, Dalian 116023, Liaoning, China \\ b University of Chinese Academy of Sciences, Beijing 100049, China
}

A R T I C L E I N F 0

Article history:

Received 13 December 2013

Accepted 23 January 2014

Published 20 July 2014

\section{Keywords:}

Alkaline anion exchange membrane

fuel cell

Gas diffusion electrode

PTFE content

Catalyst loading

Three phase boundary

\begin{abstract}
A B S T R A C T
Focused on the optimization of the gas diffusion electrode (GDE) in an alkaline anion exchange membrane fuel cell (AAEMFC), PTFE content and catalyst loading in the catalyst layer (CL) were found to have a substantial effect on the cell performance and electrochemical kinetics. The $i-V$ curves, open circuit voltage, cell resistance, in-situ electrochemical impedance spectroscopy and kinetics analysis have been used to evaluate the electrochemical properties of the fabricated GDEs. The results reveal that the optimum PTFE content in the CL of AAEMFC is 20\%. Pt loading ranged from $0.2-1.0 \mathrm{mg} / \mathrm{cm}^{2}$ was also investigated as a vital parameter for three-phase boundary, CL conductivity and catalyst utilization. Ultimately, the highest peak power density of $213 \mathrm{~mW} / \mathrm{cm}^{2}$ was achieved at $50{ }^{\circ} \mathrm{C}$ from the prepared GDE with Pt loading of $1.0 \mathrm{mg} / \mathrm{cm}^{2}$ on Pt/C and $20 \%$ PTFE in CL of AAEMFC. Considering the Pt-based catalyst effective utilization and cost, however, the platinum requirement can be diminished to close to $0.5 \mathrm{mg} / \mathrm{cm}^{2}$ in CLwithout significant performance loss.
\end{abstract}

(C) 2014, Dalian Institute of Chemical Physics, Chinese Academy of Sciences. Published by Elsevier B.V. All rights reserved.

\section{Introduction}

Recently, alkaline fuel cells (AFCs) have attracted a resurgence of interest for application involving $\mathrm{H}_{2}$ [1-4]. In particular, alkaline anion exchange membrane fuel cells (AAEMFCs), which use an alkaline anion-exchanged membrane (AEM) instead of a traditional liquid electrolyte, appear to be a potentially useful technique. Compared with conventional AFCs, AAEMFCs are superior in automotive application, owing to: (1) the elimination of electrolyte weeping, (2) reduced reactant crossover, (3) potentially simplified water management, as water is produced at the anode and consumed at the cathode, (4) a larger repertoire of effective catalytic materials, and (5) potentially reduced corrosion [2,5-7]. To fully realize these advantages, extensive efforts have been made to explore new AEMs/ionomers using novel synthesis methods, a direction which has been most often identified as an important route in advancing the field [1,8-13]. Unfortunately, AEM use requires new electrode design and raises new fabrication challenges, and little work on the electrode fabrication technology can be found in previous publications [14-16]. Research into finely optimized electrodes is therefore necessary to achieve improved cell performance.

Gas diffusion electrodes (GDEs) are frequently employed in electrochemical devices, such as fuel cells, cells for brine electrolysis, and air-metal batteries $[17,18]$. GDEs are prepared by

\footnotetext{
* Corresponding author. Tel: +86-411-84379051; Fax:+86-411-84379187; E-mail: hmyu@dicp.ac.cn

This work was supported by the National High Technology Research and Development Program of China (863 Program, 2011AA050705), the National Basic Research Program of China (973 Program, 2012CB215500), and the National Natural Science Foundation of China (21176234 and 21203191).
} 
binding PTFE to a metal net before being coated in a catalyst powder, and have the advantages of flexibility, inexpensive equipment, and ease of scale up [19]. In general, GDEs consist of two or three PTFE-bonded porous layers: a gas diffusion layer (GDL), a catalyst layer (CL), and a microporous layer (MPL) sandwiched between the GDL and the CL. The GDL acts as the backbone of the GDE, supports the MPL and CL, and is responsible for primary gas distribution [18]. The MPL usually contains a PTFE-bonded carbon-black layer which is applied onto the GDL surface. Its principle functions are: (1) to prevent flooding in the CL (water management), (2) to act as a good electrical conductor between the GDL and the $\mathrm{CL}$, and (3) to improve reactant gas distribution [20].

The CL is the core of GDE and provides reaction zones for the electrode reaction. Within the $\mathrm{CL}$, the electrode reaction occurs at the three-phase boundaries (TPBs), where the catalyst, electrolyte, and gases meet and react [3,21,22]. A state-of-the-art AAEMFC electrode usually has a CL comprising catalyst nanoparticles on carbon black, which acts as a support, mixed with an ionomer/binder $[10,23,24]$. In this case, to improve the performance of AAEMFC electrodes through increasing the stability and availability of the TPBs, either the gas transport channels for a given catalyst loading needs to be improved or the catalytic sites in the CL need to be more active. Both can be achieved by the control of the hydrophobic PTFE content and catalyst loading in the CL.

However, the PTFE content in the CL is a trade-off between the level of hydrophobic behavior of the PTFE and the conductivity of the carbon support. Conversely, high electrocatalyst loadings increase the CL thickness, and eventually to poor catalyst use. The electrocatalysts are usually noble-metal Pt-based materials, are used at both the anode and cathode, and are the major contributor to the cost of the cell $[25,26]$. Therefore, optimization of the fabrication techniques of GDEs is required to obtain enhanced AAEMFC performance and reduce electrode cost.

Recently, Tokuyama Corp. (Japan) has commercially produced alkaline electrolyte materials such as the A201 AEM and/or the anion-exchange ionomer AS-4. In a previous report, these materials showed high electrochemical stability and performance in AAEMFCs, and a maximum power density of around $450 \mathrm{~mW} / \mathrm{cm}^{2}$ in the $\mathrm{H}_{2} / \mathrm{O}_{2}$ fuel cell [27]. However, there is, as yet, no apparent consensus on the best method to improve the electrode fabrication. It is worthy to note that direct performance comparison for the published results is not crucial, since a number of the experimental conditions (like temperature, pressure, and electrode size) and electrode materials (including catalyst, current collector) can vary the cell performance, and are thus outside the scope of this report.

This paper reports the electrochemical studies of GDEs for AAEMFCs prepared with commercial AEM A201 (Tokuyama Corp.) as a standard quaternary ammonium hydroxide anion exchange membrane. To extend stable and available TPBs, the commercial ionomer AS-4 was employed in CLs to transfer hydroxide ions and bind the catalyst particles. We evaluated the effects of PTFE content and catalyst loading (Pt/C as prototype) on AAEMFC performance, and discussed the kinetic pa- rameters of the electrodes in terms of CL composition and architecture.

\section{Experimental}

\subsection{MEA fabrication}

To prepare the catalyst layer, a homogeneous suspension was formed from the desired amounts of the commercial Pt/C catalyst (70\% Pt, Johnson Matthey Inc., Britain), 5\% PTFE emulsion, and a mixture of isopropyl alcohol (IPA) and $\mathrm{H}_{2} \mathrm{O}$ (volumetric ratio of 1:1) as the solvent/dispersant. After fully suspending the emulsion by sonication, the resulting catalyst ink was quantitatively deposited on a commercial gas diffusion layer (Sunrise Power Corp.) by a hand brushing. After each pass, the solvent/dispersant was evaporated with a drier until the desired Pt loading was obtained. These GDEs were sintered at $240{ }^{\circ} \mathrm{C}$ for $30 \mathrm{~min}$ and $340{ }^{\circ} \mathrm{C}$ for $30 \mathrm{~min}$ under the $\mathrm{N}_{2}$ atmosphere to remove the surfactant and to make the PTFE hydrophobic. After that, the desired amount of ionomer AS-4 (0.2 $\mathrm{mg} / \mathrm{cm}^{2}$, Tokuyama Corp., China) was sprayed onto the surface of the as-fabricated GDE to allow $\mathrm{OH}^{-}$transport through the AEM (A201, Tokuyama Corp.) from the cathode to the anode. Finally, the GDE was cut into two pieces and the AEM sandwiched between them at $60{ }^{\circ} \mathrm{C}$ and $0.1 \mathrm{MPa}$ for $2 \mathrm{~min}$ to fabricate the membrane electrode assemblies (MEAs).

GDEs were fabricated with different PTFE contents in the CL of $10 \%, 20 \%, 30 \%$, and $40 \%$, which are named GDE-P 10 , GDE-P20, GDE-P30, and GDE-P40, respectively. To identify the impact of the Pt-based catalyst loading on the performance of AAEMFCs, four types of GDEs were prepared with different CL $\mathrm{Pt}$ loadings of $0.2,0.5,1.0$, and $1.5 \mathrm{mg} / \mathrm{cm}^{2}$, and are named GDE-LD2, GDE-LD5, GDE-LD10, and GDE-LD15, respectively.

\subsection{Characterization of CL microstructure}

To evaluate the hydrophobic properties of the prepared GDEs at each PTFE content, the contact angle tests were performed on a KRÜSS DSA100 Drop Shape Analysis System. At room temperature, $3 \mu \mathrm{l}$ of distilled water was dropped onto the electrode surface. The contact angle images were taken after 10 s. The contact angle was analyzed using the tangent method of Sessile Drop Fitting.

\subsection{Single cell tests}

The MEAs were assembled into fuel cells with an effective area of $5 \mathrm{~cm}^{2}$. The fuel cells were tested at $50{ }^{\circ} \mathrm{C}$ by passing $\mathrm{H}_{2} / \mathrm{O}_{2}(100 / 200 \mathrm{~mL} / \mathrm{min})$ at $0.05 \mathrm{MPa}$ and $100 \%$ relative humidity. The $i-V$ performance with cell resistance and in-situ electrochemical impedance spectroscopy (EIS) of each cell were measured and recorded by an electric load system (KMF2030, Kikusui Electronics Corp., Japan). The EIS experiments were carried out at the current density of 100 and 200 $\mathrm{mA} / \mathrm{cm}^{2}$ with a small amplitude alternating current of 10 $\mathrm{mA} / \mathrm{cm}^{2}$, with a frequency range of $0.1 \mathrm{~Hz}$ to $10 \mathrm{kHz}$. 


\section{Results and discussion}

\subsection{Effect of PTFE content on single cell performance}

The hydrophobicity of the CLs at each PTFE content was characterized in terms of the contact angle of the GDE surface. The contact angles images of the as-prepared GDEs are presented in Fig. 1. When the PTFE content increased from $10 \%$ to $40 \%$, the contact angles in the CL surface increased sharply from $143.0^{\circ}$ to $154.5^{\circ}$, and then slowly rose from $157.8^{\circ}$ to $158.3^{\circ}$. This means the increasing PTFE content enhances the hydrophobicity of the CLs, indicating more hydrophobic channels for gas and water transport.

Figure 2 shows the typical $i$ - $V$ curves and power density curves of the MEAs prepared at each PTFE content. The PTFE content in the CLs strongly influences the cell performance. Among the four GDEs, GDE-P20 exhibits the optimal cell performance in the tested current density window, including the activation, ohmic, and concentration-controlled regions. The

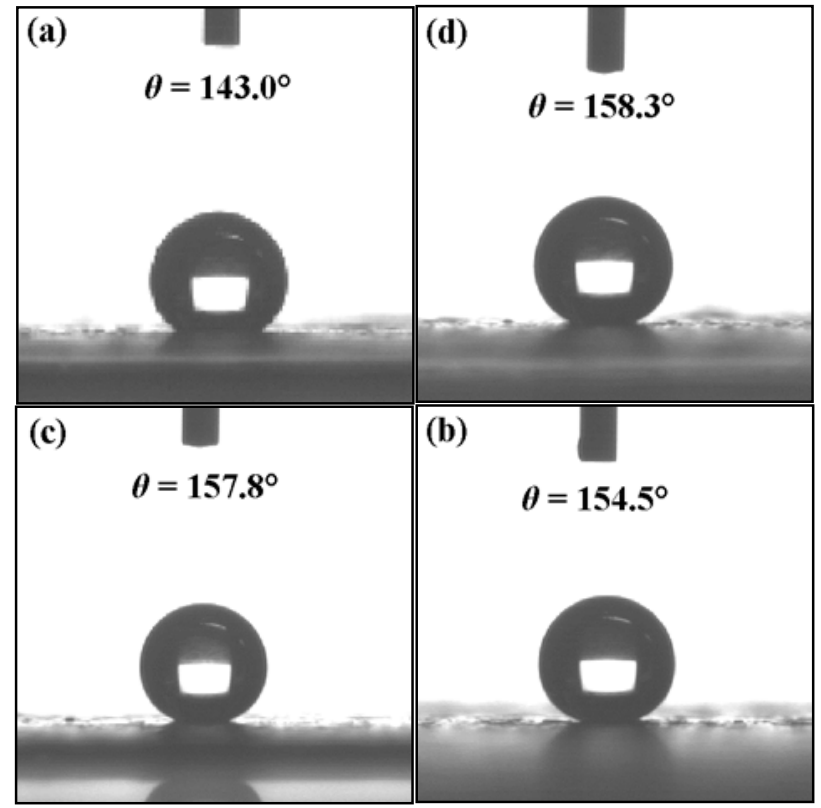

Fig. 1. Contact angle $(\theta)$ measurement images of the CLs at each PTFE content. (a) $10 \%$; (b) $20 \%$; (c) $30 \%$; (d) $40 \%$.

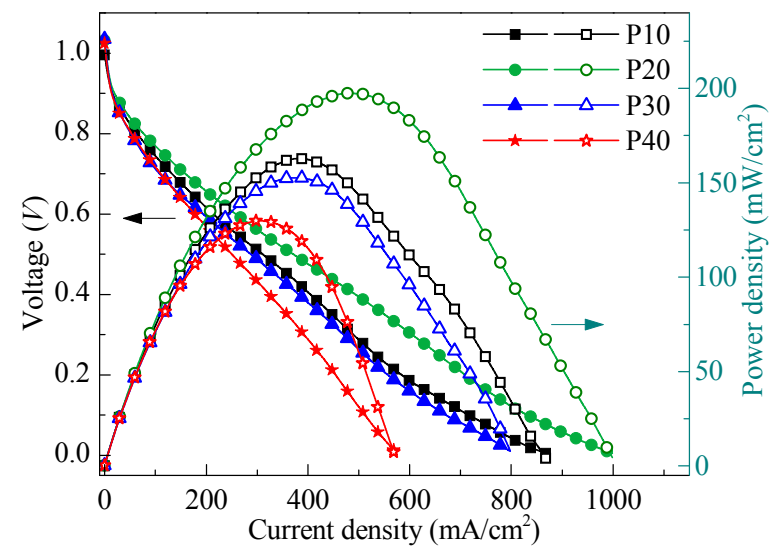

Fig. 2. $i-V$ and power density curves of the single cells at each PTFE content.
GDE-P20 cell has the highest peak power density of 197 $\mathrm{mW} / \mathrm{cm}^{2}$ and the largest current density of $998 \mathrm{~mA} / \mathrm{cm}^{2}$, which implies the catalyst dispersion/utilization and mass transport have been improved, and the catalyst active sites within the CL have been enhanced. The poor performance of GDE-P40 at a peak power density of only $130 \mathrm{~mW} / \mathrm{cm}^{2}$ may relate to the decreased conductivity of the CL caused by the high PTFE content, which is an effective insulator.

In addition, the cell open circuit voltage was monitored at each PTFE content under the $\mathrm{H}_{2} / \mathrm{O}_{2}$ AAEMFC operation. As shown in Fig. 3, the open circuit voltage increased by about 40 $\mathrm{mV}$ from $10 \%$ to $30 \%$ PTFE content, and then decreased by about $10 \mathrm{mV}$ at $40 \%$. These results indicate that increasing the PTFE in CL can hamper the reactant crossover at the interface between the CL and the AEM. The diminished open circuit voltage in GDE-P40 is an indication of the decreased conductivity in the CL.

The measured cell resistances (Fig. 4) increased linearly with the PTFE content to $30 \%$, as a result of the poor electron conductivity of the PTFE. The high cell resistance of $0.167 \Omega$ $\mathrm{cm}^{2}$ for GDE-P40 is in line with the decrease in the open circuit voltage.

The EIS spectra can provide in-situ information on the fuel cell under real operating conditions [28]. The EIS measurements were conducted at $100 \mathrm{~mA} / \mathrm{cm}^{2}$ and $200 \mathrm{~mA} / \mathrm{cm}^{2}$. The EIS results displayed in Fig. 5 show only one semicircle for each tested electrode in the experimental frequency range. The high-frequency features correspond to the ohmic resistance.

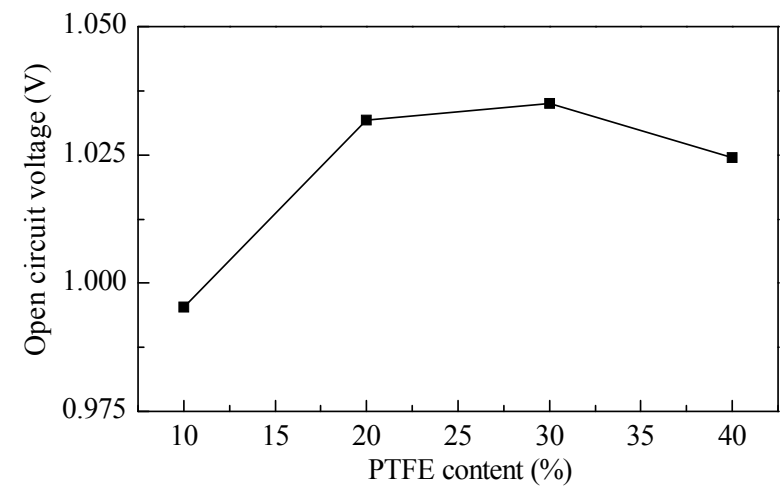

Fig. 3. Open circuit voltage of the single cell versus the PTFE content in the CL.

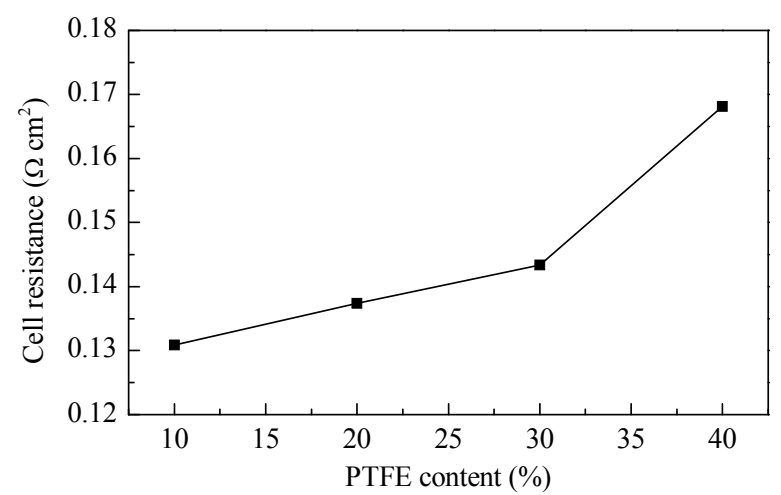

Fig. 4. Resistance of the single cell versus the PTFE content in the CL. 


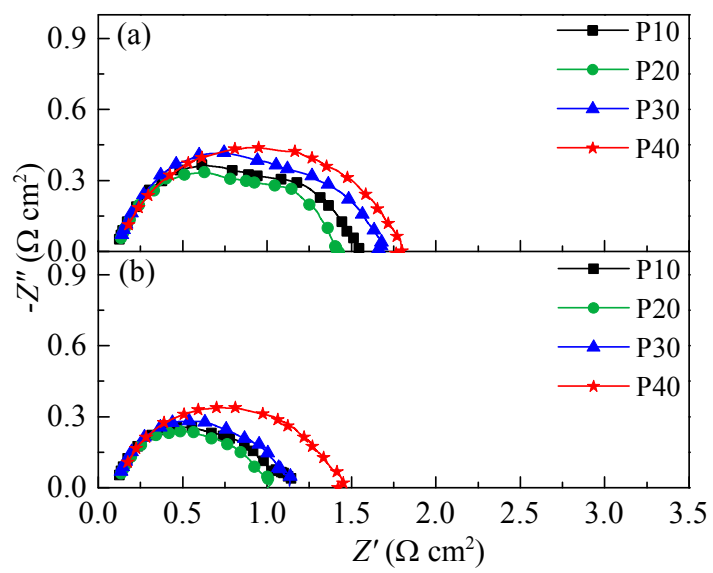

Fig. 5. In-situ EIS spectra of the single cells at each PTFE content. (a) at $100 \mathrm{~mA} / \mathrm{cm}^{2}$; (b) at $200 \mathrm{~mA} / \mathrm{cm}^{2} . Z^{\prime}$ is the real component of the impedance cell impedance vector, while $Z^{\prime \prime}$ is the imaginary component.

The medium-frequency arc, corresponding to the chargetransfer-resistance, decreased in the studied electrodes with increasing current density, which indicates a breakdown in the reaction kinetics. Figure 5 also shows that GDE-P20 has the lowest charge-transfer resistance, which is an important factor in optimum cell performance (Fig. 2). Compared with the charge-transfer resistances of other GDEs, GDE-P40 has high values at both at the current densities and hints that there is a difficult kinetic process in the electrode reaction which will be discussed below in detail.

\subsection{Effect of Pt loading on single cell performance}

To identify the impact of the Pt-based catalyst loading in the CLs, Fig. 6 shows the $i-V$ curves and power density curves of the MEAs assembled at each Pt loading. In the tested electrodes, GDE-LD10 achieved the maximum peak power density of 213 $\mathrm{mW} / \mathrm{cm}^{2}$ and the largest current density of $1118 \mathrm{~mA} / \mathrm{cm}^{2}$. The results confirm the improved TPBs for mass diffusion and electron transfer, and correspondingly decreased energy barrier for the electrode reaction, which all arose from the optimum catalyst content. Normally, the cell performance can be im-

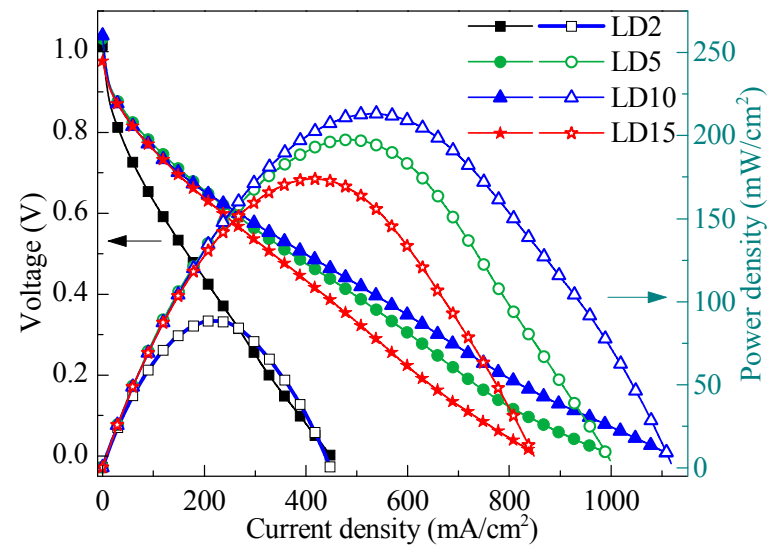

Fig. 6. $i-V$ and power density curves of the single cells at each Pt loading. proved by increasing the Pt loading, as a result of the increased catalytic sites and decreased ohmic resistance. However, GDE-LD15 with the Pt loading of $1.5 \mathrm{mg} / \mathrm{cm}^{2}$ had a lower maximum current density (ca. $848 \mathrm{~mA} / \mathrm{cm}^{2}$ ) and peak power density $\left(174 \mathrm{~mW} / \mathrm{cm}^{2}\right)$ than GDE-LD5, suggesting a relatively poor dispersion and low utilization of catalyst within the CL.

Figure 7 shows the corresponding mass peak-power-density plots derived from the above $i-V$ data. The mass peak power density decreases rapidly as the Pt loading increases, especially when the Pt loading exceeds $0.5 \mathrm{mg} / \mathrm{cm}^{2}$. Therefore, given the cost of the catalyst and the Pt utilization in AAEMFC, 0.5 $\mathrm{mg} / \mathrm{cm}^{2} \mathrm{Pt}$ as appears to be the optimum content in the electrode CL.

Furthermore, as shown in Fig. 8, the catalyst loading influences the open circuit voltage. The open circuit voltages of these cells gradually increased to the peak of $1.040 \mathrm{~V}$ at $\mathrm{Pt}$ loading of $1.0 \mathrm{mg} / \mathrm{cm}^{2}$, and then dropped by $64 \mathrm{mV}$ at Pt loading of $1.5 \mathrm{mg} / \mathrm{cm}^{2}$. This suggests that the reactant gas crossover was improved gradually owing to the thicker CL of the increasing catalyst loading, but at high loadings hampers the reactant gas crossover at the interface of the CL and AEM. Nevertheless, the low open circuit voltage of GDE-LD15 might be attributed to the high bulk resistance due to the thick CL. The low utilization of Pt catalysts may also decrease the open circuit voltage owing to the starvation of available reactant gases at the TPBs.

The measured cell resistances are given in Fig. 9. The surprisingly high cell resistance of GDE-LD2 might be ascribed to its ultra-low Pt loading and accordingly, a discontinuous conductive surface. The cell resistance is the lowest $\left(0.137 \Omega \mathrm{cm}^{2}\right)$

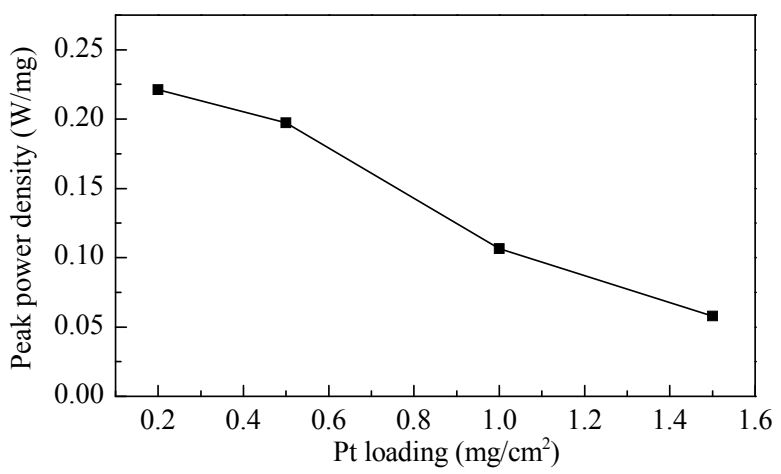

Fig. 7. Mass peak power density of the single cells versus Pt loading.

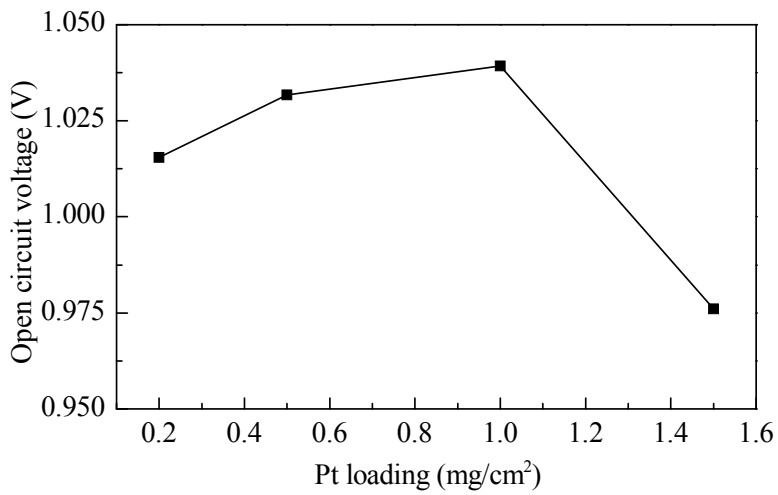

Fig. 8. Open circuit voltage of the single cells versus Pt loading. 
at Pt loading of $0.5 \mathrm{mg} / \mathrm{cm}^{2}$. Then, as the Pt loading continues to increase, the cell resistance increases to $0.175 \Omega \mathrm{cm}^{2}$, implying the resistance increase is because of thickness.

The individual characteristics of electrode reaction process can be described from the in-situ EIS test. Figure 10 shows the results of the as-prepared GDEs at each Pt loading. The EIS tests were carried out at 100 and $200 \mathrm{~mA} / \mathrm{cm}^{2}$. The charge-transfer resistance decreases significantly with increased Pt loading, meaning that there is an increase in the catalytic active sites, the TPBs are more available, and the energy barrier of the electrode reactions has decreased. GDE-LD10 has the minimum charge-transfer resistance, which coincides well with the above $i$ - $V$ curves. Besides the large charge-transfer resistance, there is another arc at the low-frequency region of GDE-LD2, revealing a mass transport resistance. Because the thickness of the CL with such a Pt loading is much thinner than that of GDE-LD5 and the other samples, gas transport will be unimpeded. Therefore, the mass transport resistance may be related to water management [29].

\subsection{Electrode reaction kinetics analysis}

To explore the electrochemical differences in these electrodes, Tafel plots were employed to extract more information about the electrode characteristics. The kinetic parameters of each electrode were obtained by fitting the $i$ - $V$ curves against a

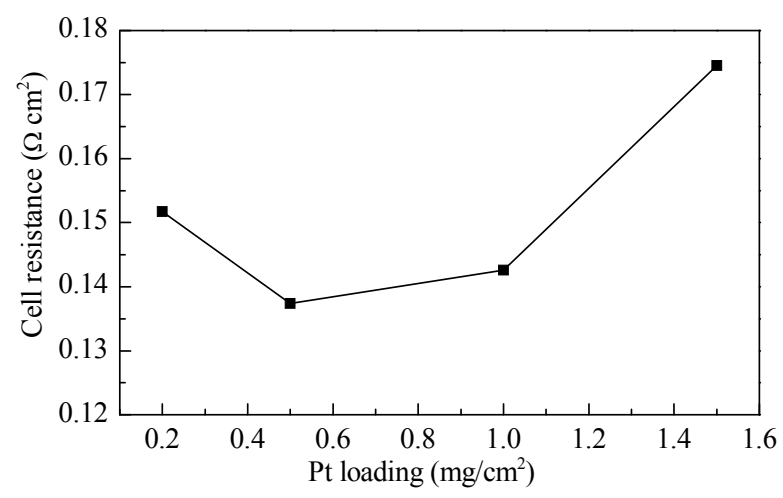

Fig. 9. Resistance of the single cells versus Pt loading.

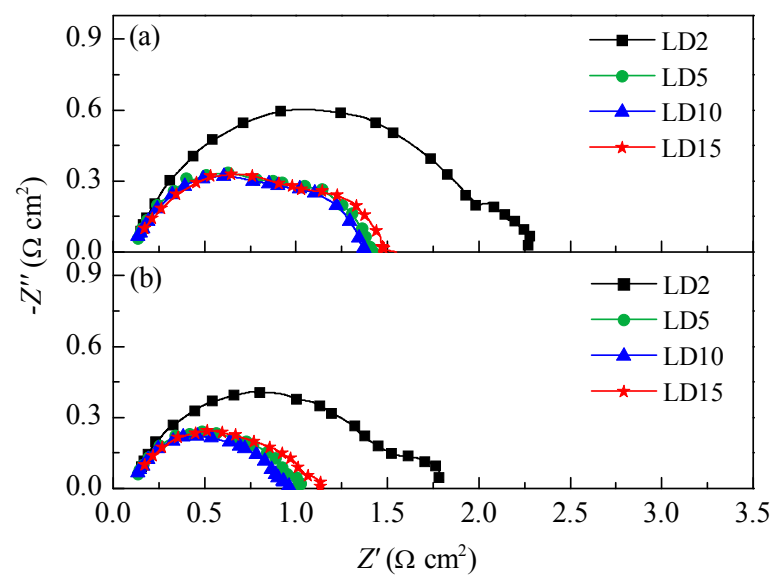

Fig. 10. In-situ EIS spectra of the cells at each Pt loading. (a) at 100 $\mathrm{mA} / \mathrm{cm}^{2}$; (b) at $200 \mathrm{~mA} / \mathrm{cm}^{2} . Z^{\prime}$ and $Z^{\prime \prime}$ see Fig. 5.
Table 1

Kinetic parameters obtained by fitting the $i-V$ curves against Eq. (1) for the electrodes with different characteristics.

\begin{tabular}{lccc}
\hline $\begin{array}{l}\text { Both at anode and } \\
\text { cathode }\end{array}$ & $b /(\mathrm{mV} / \mathrm{dec})$ & $i_{0} /\left(\mathrm{A} / \mathrm{cm}^{2}\right)$ & $R /\left(\Omega \mathrm{cm}^{2}\right)$ \\
\hline PTFE content $(\%$ in CL) & & & \\
10 & 55.8 & $7.23 \times 10^{-8}$ & 1.37 \\
20 & 54.2 & $7.41 \times 10^{-8}$ & 1.26 \\
30 & 58.7 & $1.55 \times 10^{-7}$ & 1.85 \\
40 & 57.7 & $8.94 \times 10^{-8}$ & 1.63 \\
Pt loading $\left(\mathrm{mg} / \mathrm{cm}^{2}\right)$ & & & \\
0.2 & 60.0 & $8.67 \times 10^{-8}$ & 2.44 \\
0.5 & 54.2 & $8.72 \times 10^{-8}$ & 1.26 \\
1.0 & 60.0 & $2.12 \times 10^{-7}$ & 1.29 \\
1.5 & 23.3 & $8.56 \times 10^{-15}$ & 1.83 \\
\hline
\end{tabular}

theoretical model as follows [30-32]:

$$
\begin{gathered}
E=E_{0}-b \log i-R i, \\
E_{0}=E_{r}+b \log i_{0},
\end{gathered}
$$

where $E_{r}$ is the reversible potential, taken to be $1.22 \mathrm{~V}$ for $\mathrm{H}_{2}+1 / 2 \mathrm{O}_{2} \rightarrow \mathrm{H}_{2} \mathrm{O}$ under the experimental conditions [28], $b$ is the Tafel slope, $i_{0}$ is the exchange current density, and $R$ is the overall contribution of $i$ to $E$, including the ohmic resistance, charge-transfer resistance of the hydrogen oxidation, and mass-transport resistance in the intermediate current density region.

The fitted results are listed in Table 1 . It is worth mentioning that the Tafel slope $b$ always reflects the electrode reaction activity, while the exchange current density $i_{0}$ represents the electrode reaction rate, which relates to the number of reaction sites. Since all MEAs are made from the same GDL and membrane, any differences in these parameters can be attributed to the different compositions and architectures of the CLs caused by the different PTFE contents and Pt loadings. The electrode materials and cell operating conditions in this work are also fixed, so the exchange current density $i_{0}$ is primarily dependent on the TPBs.

The results show that increasing the PTFE content generally increases $b, i_{0}$ and $R$. This means that increasing the PTFE content reduces the CL electron conductivity and the electrode reaction activity, but improves the TPBs and increases the effective reaction areas. The small $b$ and $R$ of GDE-P20 indicates this level has good electrode reaction activity and CL conductivity and further explains its excellent cell performance, and thus confirms $20 \%$ to be the optimal PTFE content in the CL.

Conversely, the increase in Pt loading results in a decrease in $b$ and $R$ but an increase in $i_{0}$, because increasing the Pt loading improves the electrode reaction activity, increases the reaction zones, and enhances the CL conductivity, so long as the Pt loading lies between 0.2 and $1.0 \mathrm{mg} / \mathrm{cm}^{2}$. Electrodes with $\mathrm{Pt}$ loading $1.0 \mathrm{mg} / \mathrm{cm}^{2}$ have better CL conductivity and improved TPBs, meaning this is the optimal Pt loading. Considering the open circuit voltage of GDE-LD15, its tiny exchange current density may be related to the concentration distribution of the reactants in the thick CL.

\section{Conclusions}

The effects of the PTFE content and Pt loading on AAEMFC 


\section{Graphical Abstract}

Chin. J. Catal., 2014, 35: 1091-1097 doi: 10.1016/S1872-2067(14)60050-4

Effect of gas diffusion electrode parameters on anion exchange membrane fuel cell performance

Donglei Yang, Hongmei Yu*, Guangfu Li, Wei Song, Yanxi Liu, Zhigang Shao

Dalian Institute of Chemical Physics, Chinese Academy of Science; University of Chinese Academy of Sciences
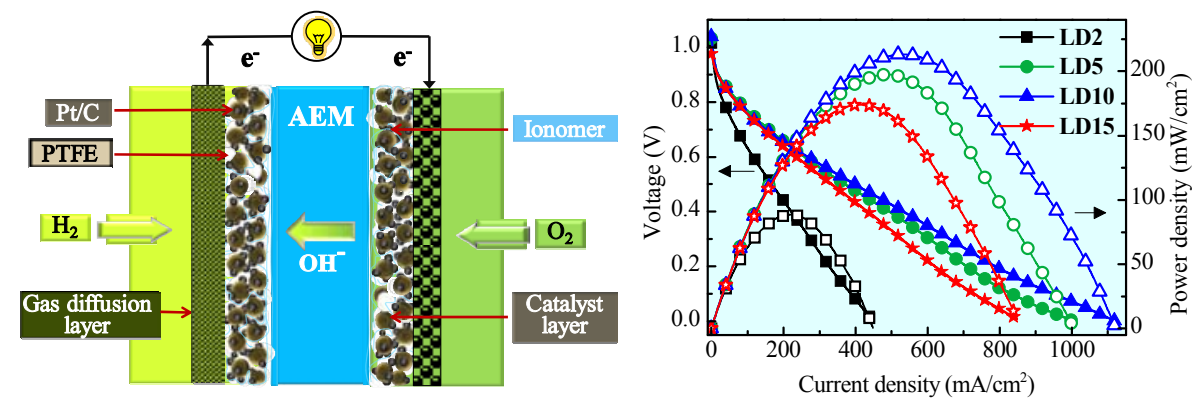

The performance of the prepared gas diffusion electrode in an anion exchange membrane fuel cell has been significantly improved using an optimized PTFE content and Pt loading in the Pt-based catalyst layer.

performance and electrode kinetics were evaluated and investigated. The results show that the fabricated GDE-P20 has the optimal peak power density of $197 \mathrm{~mW} / \mathrm{cm}^{2}$ at $50{ }^{\circ} \mathrm{C}$, meaning the optimum PTFE content in the CL is $20 \%$. In addition, based on the various cell measurements and fitted kinetic parameters, the Pt loading (ranging from 0.2 to $1.0 \mathrm{mg} / \mathrm{cm}^{2}$ ) was observed as a crucial role in augmenting the TPBs, the electron conductivity, and catalyst utilization in CLs. The best performance of GDE for AAEMFCs had a peak power density of 213 $\mathrm{mW} / \mathrm{cm}^{2}$ with Pt loading $1.0 \mathrm{mg} / \mathrm{cm}^{2}$ of $70 \% \mathrm{Pt} / \mathrm{C}$, and $20 \%$ PTFE in the CL. To increase utilization of the Pt-based catalyst and reduce its cost, this work confirmed that the Pt loading could be diminished to near $0.5 \mathrm{mg} / \mathrm{cm}^{2}$ in the CL without obvious performance loss.

\section{References}

[1] Wang Y J, Qiao J L, Baker R, Zhang J J. Chem Soc Rev, 2013, 42: 5768

[2] Varcoe J R, Slade R C T. Fuel Cells, 2005, 5: 187

[3] Matsumoto K, Fujigaya T, Yanagi H, Nakashima N. Adv Funct Mater, 2011, 21: 1089

[4] Merle G, Wessling M, Nijmeijer K. J Membr Sci, 2011, 377: 1

[5] Bidault F, Brett D J L, Middleton P H, Brandon N P. J Power Sources, 2009, 187: 39

[6] Pan J, Chen C, Zhuang L, Lu J T. Acc Chem Res, 2012, 45:473

[7] Tamain C, Poynton S D, Slade R C T, Carroll B, Varcoe J R. J Phys Chem C, 2007, 111: 18423

[8] Arges C G, Parrondo J, Johnson G, Nadhan A, Ramani V. J Mater Chem, 2012, 22: 3733

[9] Poynton S D, Zeng R, Kizewski J, Ong A L, Varcoe J R. ECS Transactions, 2012, 50: 2067

[10] Deavin O I, Murphy S, Ong A L, Poynton S D, Zeng R, Herman H, Varcoe J R. Energy Environ Sci, 2012, 5: 8584

[11] Liu L L, Zhang J, Qiao J L. Chem Res Chin Univ (刘玲玲, 张璟, 乔锦 丽. 高等学校化学学报), 2012, 8: 1842

[12] Xu T W, Wu Y H, Luo J Y. Membr Sci Technol (徐铜文, 吴永会, 罗

\section{靖艺. 膜科学与技术), 2011, 31: 192}

[13] Zhu R J, Zhang X R, Wang T, Wang D. Chin J Power Sources (朱荣杰, 张新荣, 王涛, 王东. 电源技术), 2013, 37: 575

[14] Kim J-H, Yonezawa S, Takashima M. Int J Hydrogen Energy, 2010, 35: 8707

[15] Bunazawa H, Yamazaki Y. J Power Sources, 2008, 182: 48

[16] Kim H, Zhou J F, Ünlü M, Anestis-Richard I, Joseph K, Kohl P A. Electrochim Acta, 2011, 56: 3085

[17] Hayashi K, Furuya N.J Electrochem Soc, 2004, 151: A354

[18] Huang N K, Wang S Z, Li L X. Chin J Power Sources (黄乃科, 王曙中, 李灵忻. 电源技术), 2003, 27: 329

[19] Marini S, Salvi P, Nelli P, Pesenti R, Villa M, Kiros Y. Int J Hydrogen Energy, 2013, 38: 11496

[20] Millington B, Du S F, Pollet B G. J Power Sources, 2011, 196: 9013

[21] Kim Y B, Holme T P, Guer T M, Prinz F B. Adv Funct Mater, 2011, 21: 4684

[22] Kubo D, Tadanaga K, Hayashi A, Tatsumisago M. J Power Sources, 2013, 222: 493

[23] Ünlü M, Zhou J F, Anestis-Richard I, Kim H, Kohl P A. Electrochim Acta, 2011, 56: 4439

[24] Lu S F, Pan J, Huang A B, Zhuang L, Lu J T. Proc Natl Acad Sci (USA), 2008, 105: 20611

[25] Yan Z Y, Li B, Yang D J, Ma J X. Chin J Catal (严泽宇, 李冰, 杨代军, 马建新. 催化学报), 2013, 34: 1471

[26] Zhang H Y, Cao C H, Zhao J, Lin R, Ma J X. Chin J Catal (张海艳, 曹春 晖, 赵健, 林瑞, 马建新. 催化学报), 2012, 33: 222

[27] Fukuta K. Electrolyte Materials for AMFCs and AMFCs Performance. Presented at the 2011 AMFC Workshop, 2011

[28] Varcoe J R, Slade R C T, Wright G L, Chen Y L. J Phys Chem B, 2006, 110: 21041

[29] Mamlouk M, Scott K, Horsfall J A, Williams C. Int J Hydrogen Energy, 2011, 36: 7191

[30] Kim J, Lee S M, Srinivasan S, Chamberlin C E. J Electrochem Soc, 1995, 142: 2670

[31] Squadrito G, Maggio G, Passalacqua E, Lufrano F, Patti A. J Appl Electrochem, 1999, 29: 1449

[32] Carmo M, Doubek G, Sekol R C, Linardi M, Taylor A D. J Power Sources, 2013, 230: 169 


\title{
气体扩散电极参数对阴离子交换膜燃料电池性能的影响
}

\author{
杨冬蕾 ${ }^{a}, \mathrm{~b}$, 俞红梅 ${ }^{\mathrm{a}}{ }^{*}$, 李光福 ${ }^{\mathrm{a}}$, 宋 微 ${ }^{\mathrm{a}}$, 刘艳喜 ${ }^{\mathrm{a}}$, 郡志刚 ${ }^{\mathrm{a}}$ \\ ${ }^{\mathrm{a}}$ 中国科学院大连化学物理研究所, 清洁能源国家实验室, 辽宁大连 116023 \\ b国科学院大学, 北京 100049
}

摘要: 优化了碱性阴离子交换膜燃料电池(AAEMFC)使用的气体扩散电极(GDE), 发现催化层中PTFE含量与催化剂担载量对电池 性能与其电化学动力学特征影响很大. 采用 $i-V$ 曲线, 开路电压, 电池内阻与在线的电化学阻抗谱与动力学分析, 评估了所制GDE的 电化学性能. 在所研究的AAEMFC电极催化层中, PTFE的最佳含量是 $20 \%$, Pt载量对膜电极三相界面、催化层导电性与催化剂利用 率的影响极大. 当制备的GDE催化层中 $\mathrm{Pt} / \mathrm{C}$ 的Pt载量为 $1.0 \mathrm{mg} / \mathrm{cm}^{2}$, PTFE含量为 $20 \%$ 时, AAEMFC的峰电流密度在 $50{ }^{\circ} \mathrm{C}$ 达到了 213 $\mathrm{mW} / \mathrm{cm}^{2}$. 兼顾Pt催化剂的利用率与成本, 在没有明显影响电池性能的情况下, Pt的担载量可降至 $0.5 \mathrm{mg} / \mathrm{cm}^{2}$.

关键词: 碱性阴离子交换膜燃料电池; 气体扩散电极; PTFE含量; 催化剂担载量; 三相界面

收稿日期: 2013-12-13. 接受日期: 2014-01-23. 出版日期: 2014-07-20.

*通讯联系人. 电话: (0411)84379051; 传真: (0411)84379187; 电子信箱: hmyu@dicp.ac.cn

基金来源：国家高技术研究发展计划(863计划, 2011AA050705); 国家重点基础研究发展计划(973计划, 2012CB215500); 国家自 然科学基金(21176234, 21203191).

本文的英文电子版由Elsevier出版社在ScienceDirect上出版(http://www.sciencedirect.com/science/journal/18722067). 